\title{
Collection periods in the in vitro establishment of raspberry tree cultivars
}

Cíntia de Moraes Fagundes ${ }^{1, *}$, Roseane Maidana Moreira ${ }^{1}$, Cari Rejane Fiss Timm ${ }^{1}$, Jacqueline Barcelos da Silva ${ }^{1}$, Luis Eduardo Corrêa Antunes ${ }^{2}$ and Márcia Wulff Schuch ${ }^{1}$

${ }^{1}$ Universidade Federal de Pelotas, Pós-Graduação em Agronomia, Avenida Eliseu Maciel, s/n, 96160-000, Pelotas, Rio Grande do Sul, Brazil. ${ }^{2}$ Embrapa Clima Temperado, BR 392, km 78, 96010-971, $9^{\circ}$ Distrito, Monte Bonito - Pelotas, Rio Grande do Sul, Brazil. *Corresponding author, E-mail: cintiafagundes_15@hotmail.com

\begin{abstract}
The raspberry tree, a species from the Rosaceae family and the Rubus genus, is included in the group of small fruit that has been drawing the attention of the global consuming market for carrying antioxidant properties and substances capable of fighting free radicals, bringing health benefits. The objective of this work was to evaluate the effect of collection periods on the in vitro establishment of raspberry trees (Rubus idaeus L.). Explants were collected in different seasons of the year (winter, spring, summer and autumn), and were inoculated in a MS culture medium. The experimental design was totally randomized, and arranged in a factorial scheme. At 28 days, the following variables were evaluated: oxidation, fungal and bacterial contamination survival and establishment. There was less phenolic oxidation in raspberry tree explants collected in winter. Explants contamination by endogenic bacteria occurred in higher percentages in winter. Although summer was the season of the year with higher percentage of explants' phenolic oxidation for both cultivars, the highest in vitro establishment percentages for the Heritage cultivar occurred in summer and fall. However, for the Fallgold cultivar, spring and winter were the seasons with greater in vitro establishment.
\end{abstract}

Key words: Tissues culture, seasonality, Rubus idaeus, phenolic oxidation.

\section{INTRODUCTION}

The increase in small fruit growing is a result, mainly, of an increase in the demand for these species both nationally and internationally. Among them, raspberries stand out for their coloration, taste and aroma (Antoniolli et al., 2011), and for being rich in nutrients such as anthocyanins, amino acids and vitamins (Han et al., 2007).

In Brazil, raspberry growing is still incipient. However, planted area has increased in the last couple of years. In 2004, raspberries occupied 40 hectares (Raseira et al., 2004). It is estimated that this area has doubled or tripled, constituting 100 to 150 cultivated hectares, distributed in the states of Rio Grande do Sul, Santa Catarina, Minas Gerais and São Paulo (Gonçalves et al., 2011; Kretzschmar et al., 2013).

The success of a domestic or commercial orchard is connected directly to seedling quality, planting and management care. Seedlings are, in reality, the basis of an orchard since its success or failure depends on them (Chalfun and Pio 2012). Seedlings collection is needed both to start an orchard and to renovate an existing orchard. Raspberry orchard renovation practices must be carried out every three or four years (Tezotto-Uliana and Kluge 2013), to preserve plant quality and productivity. It is important to highlight that, for both planting and replanting, it is essential for the material to be of good origin and with excellent phytosanitary characteristics to develop sustainable productivity, i.e., social and environmental responsibility towards the use of agrochemicals and for the production of quality fruit (KaraklajiĆ-Stajić et al., 2012).

The raspberry tree, despite producing fruit with great number of viable seeds, it is not usually propagated sexually, since seeds show highly complex dormancy (Tezotto-Uliana and Kluge 2013), and high probability of genetic variations, which make this method not viable for seedlings commercial production.

On the other hand, vegetative or asexual propagation allows for the development a plant genetically identical to the parent through the separation of the vegetative parts of a tissue (roots, shoots and leaves) (Toogood 2007). Main raspberry propagation takes place through rooting of the remaining pruning material (shoots) and root cuttings, removal of roots grown between the lines and tissue in vitro culture (Oliveira et al., 2010; Ilha 2012).

Tissue culture applications in raspberry trees have not been explored sufficiently due to the lack of efficient establishment protocols for most cultivars. In general, the period of the year in which explants collection is collected may alter their responses, influenced by the climate such as temperature and photoperiod. In summer, growth and development are favored whereas in fall and winter, the endogenous hormonal balance is unfavorable to plant development, culminating with buds dormancy (Scherer-Salvaro et al., 2009).

Taking into account that the availability of healthy raspberry seedlings is considered a determining factor for commercial orchards development, the production of seedlings through micro-propagation may be an alternative for the production of certified seedlings. The objective of the present work was to evaluate the effect of explants collection periods and the behavior of the tested cultivars to develop protocols for the in vitro establishment of 
raspberry trees.

\section{MATERIALS AND METHODS}

The experiment was conducted at Faculdade de Agronomia Eliseu Maciel (FAEM) Fruit Plants Propagation Laboratory, Department of Plant Science, Federal University of Pelotas (UFPel), Capão do Leão, RS, during the growth seasons of 2013-2014 and 2014-2015,

For the in vitro establishment of the raspberry tree, this study used two-year-old parent plants from the UFPel Germplasm Active Bank kept in vases of nine liters and grown in Plantmax ${ }^{\circledR}$ substrate (Figure 1). Plants were irrigated daily, alternating water irrigation with nutritive solution (Schuch and Peil, 2011), every 15 days, to meet the hydric and nutritional needs of the culture. To reduce in vitro contamination, parent plants were sprayed every two days, for one year, with the bactericide $\left(\right.$ Kasumin $\left.^{\circledR}\right)$ and the fungicide $\left(\right.$ Cercobin $\left.{ }^{\circledR}\right)$ at dosages of $3 \mathrm{~mL} \mathrm{~L}^{-1}$ and $0,7 \mathrm{~g} \mathrm{~L}^{-1}$, respectively.

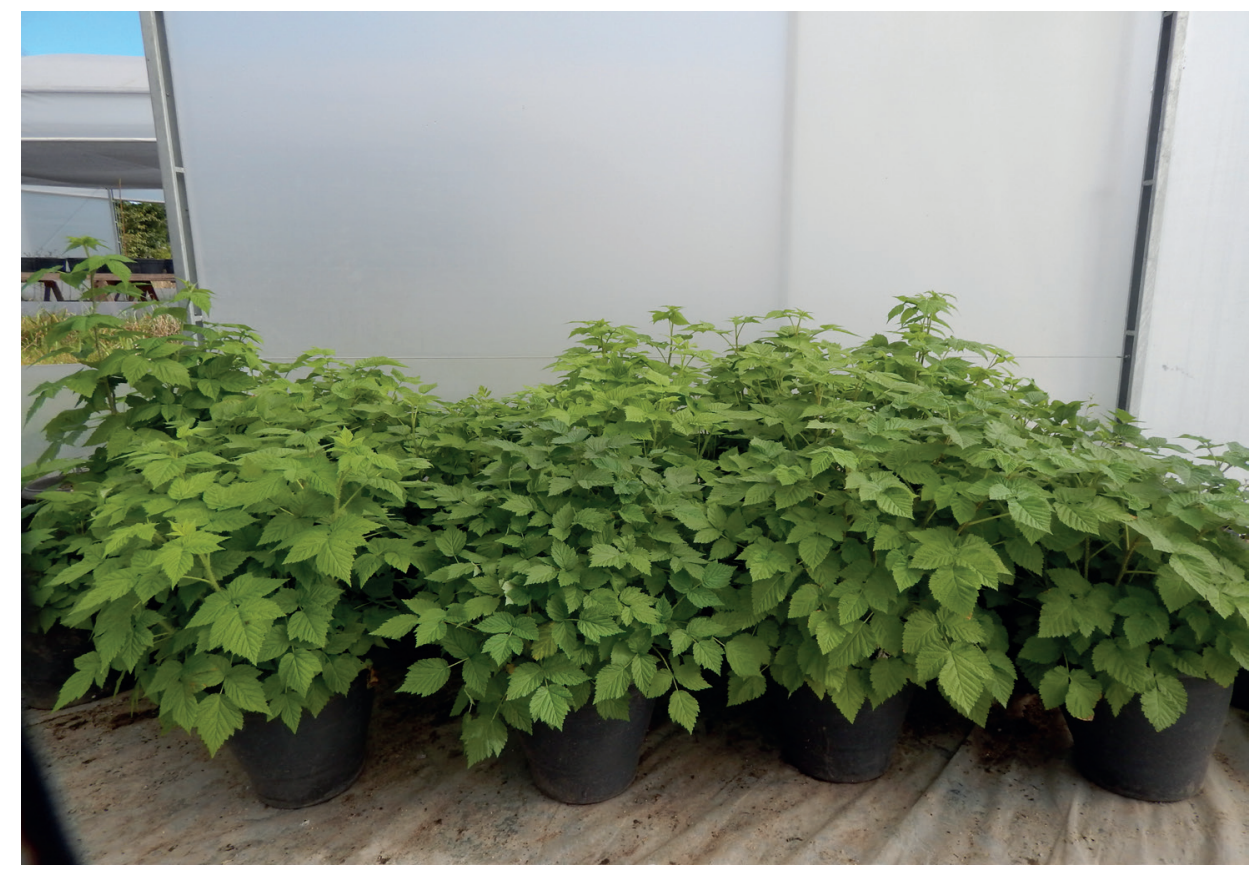

Figure 1. Raspberry parent plants kept in vases of 9 liters and grown in commercial substrate, FAEM/UFPel, Pelotas-RS, 2014, Photo: Fagundes, 2014.

The experimental design was totally randomized in a factorial scheme, with four replications. Each replication was composed of 25 tubes with one explant per tube. Treatment factor A tested seasons of the year (winter, spring, summer and fall) and factor B the cultivars (Fallgold and Heritage).

Raspberry tree explants were collected with approximately two centimeters and two buds, and such shoots had their leaves removed during collection (Figure 2). Firstly, explants were disinfected with alcohol 70\%, under agitation, for one minute, and later immersed in sodium hypochlorite ( $2.5 \%$ of active chloride) with the addition of two drops of Tween 20 and submitted to agitation again (15 minutes). Next, the disinfected material washed thrice with autoclaved distilled water and sterilized in a laminar flow chamber was used for the posterior isolation of explants.

The culture medium where explants were inoculated was constituted of salts and vitamins in a MS medium (Murashige and Skoog 1962), $100 \mathrm{mg} \mathrm{L}^{-1}$ de myo-inositol, $30 \mathrm{~g} \mathrm{~L}^{-1}$ of sucrose, with the $\mathrm{pH}$ adjusted to 5.8 prior to the inclusion of the agar $\left(7 \mathrm{~g} \mathrm{~L}^{-1}\right)$. Next, test tubes $(150 \mathrm{x} 20 \mathrm{~mm})$ with $7 \mathrm{~mL}$ of the culture medium were closed with aluminum paper and autoclaved $\left(121^{\circ} \mathrm{C}\right.$ and $\left.1.5 \mathrm{~atm}\right)$ for 20 minutes.

After inoculation, explants were kept in the dark, inside cardboard boxes with sealed tops, for seven days. Next, they were transferred to a growing room with photoperiod of 16 days under the light and 8 days in the dark, with radiation at $27 \mu \mathrm{mol} \mathrm{m}^{-2} \mathrm{~s}^{-1}$, temperature at $25 \pm 2^{\circ} \mathrm{C}$ and humidity at $50 \%$.

The following evaluations were realized: oxidation, fungal and bacterial contamination, survival and establishment. Plant oxidation (Figure $3 \mathrm{~A}$ ), fungal (Figure $3 \mathrm{~B}$ ) and bacterial (Figura $3 \mathrm{C}$ ) contamination percentages were evaluated at 28 days of cultivation. Tubes with fungal and bacterial contamination were eliminated throughout the experiment. At 45 days of cultivation, the material was evaluated in regard to survival (Figure 3 D), indicated by the green coloration of the nodal segment and establishment, determined by the development of the first leaves and the presence of shoots. 


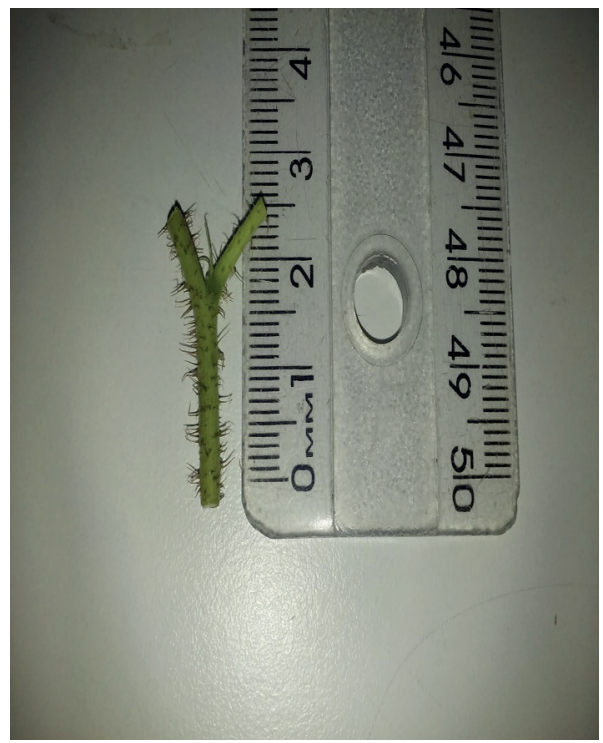

Figure 2. Raspberry tree explants collected from a parent plant, FAEM/UFPel, Pelotas-RS, 2014-2015, Photo: Fagundes, 2014-2015.

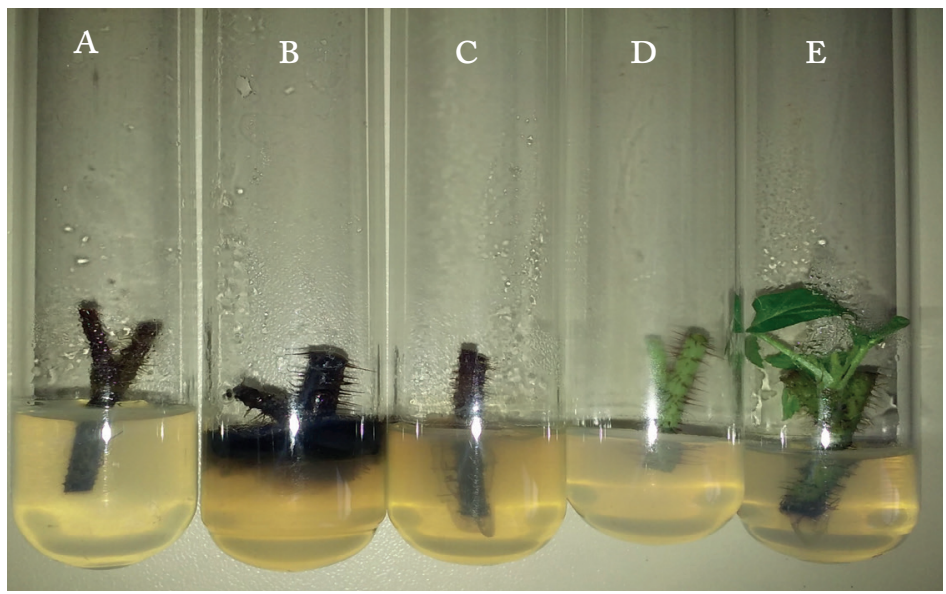

Figure 3. Raspberry tree explants inoculated in vitro, under oxidation stage (A), fungal contamination (B), bacterial contamination (C), survival (D) and established (E), FAEM/UFPel, Pelotas-RS, 2014-2015, Photo: Fagundes, 20142015.

Data normality was analyzed by the Shapiro Wilk test, homocedasticity by the Hartley test, and residue independence by graphic analysis. Later data were submitted to an analysis of variance by the $F$ test $(p \leq 0.05)$. With the confirmation of the statistical significance, seasons effects were compared by the Duncan test $(\mathrm{p} \leq 0.05)$ and cultivars by the $t$ test $(\mathrm{p} \leq 0.05)$. The presence of correlations among dependent variables in the study was analyzed through the Pearson's correlation coefficient, in general, for the whole experiment.

\section{RESULTS AND DISCUSSION}

There was no significance for season, cultivar and season $\mathrm{x}$ cultivar interaction for the fungal contamination percentage variable (Table 1). For the oxidation, bacterial contamination and survival percentage variables, there was only the effect for season (Table 2). For the establishment percentage, there was significance for interaction among the tested factors (Table 3).

In regard to oxidation, summer was the season with the highest percentage (22.86\%); however, it did not differ statistically from spring (18.67\%) (Table 2). This fact may be related to the progressive increase in average temperatures, which favors an increase in the physiological activities of the parent plant, causing greater production of phenolic composites when explants were introduced in vitro. In addition, another factor that can be taken into consideration is the solar radiation in the region, which increased proportionally to each season's average temperatures.

The light radiated during the summer by parent plants located in protected environment may also have contributed to the increase in oxidation, since they are highly dependent on the presence of light plus other factors such as an increasein temperature. Another associated circumstance is that as the average temperatures and solar radiation (Table 5) 
Table 1. Analysis of variance for the variables analyzed, UFPel, Pelotas/RS, 2014/15.

\begin{tabular}{clc}
\hline Fungal contamination & $\mathrm{F}$ & $p$ \\
\hline Season & 2.14 & $0.1271^{*}$ \\
Cultivar & 0.00 & $1.00 *$ \\
Cultivar*Season & 0.00 & $1.00 *$ \\
\hline Oxidation & $\mathrm{F}$ & $p$ \\
\hline Season & 7.25 & 0.002 \\
\hline Bacterial contamination & $\mathrm{F}$ & $p$ \\
\hline Season & 8.25 & 0.0008 \\
\hline Survival & $\mathrm{F}$ & $p$ \\
\hline Season & 6.02 & 0.0055 \\
\hline Establishment & $\mathrm{F}$ & $p$ \\
\hline Cultivar*Season & 4.00 & 0.0252 \\
\hline
\end{tabular}

* Values of $p>0.05$ showed no significance.

Table 2. Nodal segments oxidation, bacterial contamination and survival percentages for cultivars Fallgold and Heritage in function of seasons of the year. UFPel, Pelotas/RS, 2014/15.

\begin{tabular}{lcccccc}
\hline $\begin{array}{l}\text { Seasons of } \\
\text { the year }\end{array}$ & $\begin{array}{c}\text { Oxidation } \\
(\%)\end{array}$ & $\begin{array}{c}\text { Standart } \\
\text { deviation }\end{array}$ & $\begin{array}{c}\text { Bacterial } \\
\text { contamination } \\
(\%)\end{array}$ & $\begin{array}{c}\text { Standart } \\
\text { deviation }\end{array}$ & $\begin{array}{c}\text { Survival } \\
(\%)\end{array}$ & $\begin{array}{c}\text { Standart } \\
\text { deviation }\end{array}$ \\
\hline Winter & $10.00^{1} \mathrm{c}^{2}$ & 4.78 & $25.71 \mathrm{a}$ & 3.15 & 34.00 & $\mathrm{a} 10.65$ \\
Spring & $18.67 \mathrm{ab}$ & 4.84 & $20.57 \mathrm{~b}$ & 5.38 & 35.33 & $\mathrm{a} 7.33$ \\
Summer & $22.86 \mathrm{a}$ & 6.41 & $20.00 \mathrm{~b}$ & 5.23 & 20.57 & $\mathrm{~b} 10.43$ \\
Fall & $15.33 \mathrm{bc}$ & 3.01 & $13.14 \mathrm{c}$ & 5.23 & 40.67 & $\mathrm{a} 8.54$ \\
\hline
\end{tabular}

${ }^{1}$ Means of 4 replications. 2Means followed by the same letter in the column showed no difference among themselves by the Duncan test $(\mathrm{p} \leq 0.05)$.

Table 3. Fallgold and Heritage cultivars nodal segments establishment percentages in function of seasons of the year, UFPel, Pelotas/RS, 2014/15,

\begin{tabular}{llcccc}
\hline Seasons of the year & \multicolumn{7}{c}{ Cultivars } \\
\cline { 2 - 6 } & Fallgold & Standart deviation & Heritage & Standart deviation \\
\hline Winter & $12.00^{1} \mathrm{ab}^{2} *$ & 0.00 & $6.00 \mathrm{~b}$ & 2.30 \\
Spring & $13.33 \mathrm{a}$ & $*$ & 2.30 & $4.00 \mathrm{~b}$ & 4.00 \\
Summer & $9.33 \mathrm{~b}$ & $*$ & 2.31 & $18.67 \mathrm{a}$ & 4.61 \\
Fall & $5.33 \mathrm{c}$ & $*$ & 2.30 & $16.00 \mathrm{a}$ & 4.00
\end{tabular}

${ }^{1}$ Means of 4 replications. 2Means followed by the same lower case letter in the column showed no difference among themselves by the Duncan test $(p \leq 0.05)$ by comparing the seasons of the year for each cultivar. * Significant by the $t$ test $(p \leq 0.05)$ by comparing cultivars in each season of the year.

decrease during the year, the enzymatic composites production levels predisposed to oxidation diminish. This behavior can be observed in fall and winter (Table 2). These assumptions are in agreement with Rosa et al. (2006), who by studying the in vitro establishment of Mate herb (Ilex paraguariensis St, Hil,) in different periods of the year, also observed that the highest phenolic composite oxidation rate (30\%) was for explants collected in summer (Table 2).

In regard to bacterial contamination, the highest percentages (Table 2) were found in winter $(25.71 \%)$, when compared to other seasons of the year. This may have been caused by the fact that vases with parent plants were placed in a protected environment (greenhouse), and, due to the high rainfall and external relative air humidity occurred during this period of the year, the lateral drapes of the greenhouse were kept closed. This increased the relative humidity of the internal environment, facilitating the development of endogenous microorganisms. In addition, plants stress may have occurred, making them more fragile and prone to a contaminants attack. The result found for this variable is in contrast with the percentages obtained by Erig and Fortes (2002) when evaluating pear tree (Pyrus spp,) cultivars and different explants collection periods to isolate in vitro meristems. They observed greater explants contamination by bacteria in summer for the three cultivars (Garber, Smith and Carrick - 17.7\%, $15.5 \%$ and $5.1 \%)$. They believe that this response is related to temperature increase, which makes plants breathing rate increase, promoting water loss and, consequently, causing physiological stress on vegetal tissues, exposing them to the attack of endogenous microorganisms. 
In regard to explants survival (Table 2), summer was the only season of the year that differed statistically for the others, showing the lowest percentages (20.57\%). This low survival rate in summer may be related to the high effective oxidation level. As opposed to this observation, Buzkan et al. (1997) obtained the lowest percentages of meristems survival for sweet cherry tree (Prunus avium L.) established in the fall.

For the in vitro establishment variable, for the Heritage cultivar, seasons of the year (18.67\%) and fall (16\%) showed no statistical difference; however, summer showed superior values (Table 3). This can be attributed to the fact that the cultivar is the most cultivated in the world due to its great adaptability to several regions around the world.

On the other hand, establishment rate was lower in the spring, although survival (35.33\%) was higher in the summer (20.57\%) (Table 2). Erig et al. (2003), working with blueberry (Vaccinium ashei Reade) culture, verified that although the survival percentage of the nodal segments was relatively high (40.75\%), the establishment percentage of the survived was low (8.09\%). The authors report that even with a high explants survival rate, this cannot be used as an indication that plant establishment will occur form these explants. Although explants survival represents a timely condition for their development, physiological intrinsic factors (differences among cultivars) as well as chronological factors such as cultivars incubation time in the culture medium may affect in vitro establishment.

Table 4. Pearson correlation coefficients and $p$ values between dependent variables, UFPel, Pelotas/RS, 2014/15,

\begin{tabular}{|c|c|c|c|c|c|}
\hline Variables & Oxidation & $\begin{array}{c}\text { Fungal } \\
\text { contamination }\end{array}$ & $\begin{array}{c}\text { Bacterial } \\
\text { contamination }\end{array}$ & Survival & Establishment \\
\hline & (1) & (2) & (3) & (4) & (5) \\
\hline \multirow[t]{2}{*}{ (1) } & 1.000 & $0.139 *$ & -0.382 & -0.458 & 0.065 \\
\hline & & $0.450 * *$ & 0.031 & 0.008 & 0.724 \\
\hline \multirow[t]{2}{*}{ (2) } & & 1.000 & 0.076 & -0.657 & 0.210 \\
\hline & & & 0.677 & $<0.0001$ & 0.248 \\
\hline \multirow[t]{2}{*}{ (3) } & & & 1.000 & 0.032 & -0.524 \\
\hline & & & & 0.860 & 0.002 \\
\hline (4) & & & & 1.000 & $\begin{array}{r}-0.345 \\
0.053\end{array}$ \\
\hline (5) & & & & & 1,000 \\
\hline
\end{tabular}

* Pearson correlation coefficient; and ** $\mathrm{p}$ values.

Explants tissues continued alive, since they remained with a green coloration due to the presence of chlorophyll; however, they did not give out leaves and shoots, which characterizes in vitro establishment. This can be explained by the degree of development of the bud explant. It can be inferred that some explants, mainly those isolated from the budding median region, would be with more developed buds and with the stalk more lignified than those of the apex, affecting oxidation, survival and establishment.

The Fallgold cultivar, as opposed to the Heritage, showed higher percentage of established explants in the spring (13.33\%), with no statistical difference for the winter establishment rate (12\%). This can be related to the natural behavior of this cultivar, since it shows a precocity period greater than that of the Heritage in regard to both physiological development and fruit maturation.

Table 5. Means for temperature and air relative humidity inside the greenhouse, UFPel, Pelotas/RS, 2014/15.

\begin{tabular}{ccc}
\hline Seasons of the year & T mean $\left({ }^{\circ} \mathrm{C}\right)$ & UR $(\%)$ \\
\hline Winter & 18.3 & 71 \\
Spring & 27.0 & 62 \\
Summer & 30.0 & 60 \\
Fall & 22.0 & 64 \\
\hline
\end{tabular}

In general, the correlations (Table 4) verified between dependent variables were negative for the whole experiment. The highest negative correlation coefficient occurred between fungal contamination and survival $(\mathrm{r}=-0.66, p<0.01)$, showing that the increase in fungal contamination led to a decrease in survival percentage. This same behavior was verified for bacterial contamination where an increase represented a reduction in explants establishment reduction $(\mathrm{r}=-0.52, p=0.01)$. 
Negative correlations were found, but with lower coefficients, between oxidation and survival percentages $(\mathrm{r}=$ - 0.46, $p=0.01)$, and also between oxidation and bacterial contamination $(\mathrm{r}=-0.38, p=0.03)$ and survival and establishment $(\mathrm{r}=-0.34, p=0.05)$. Correlation with negative Person coefficient between oxidation and survival percentile suggests that an increase in oxidation percentage results in a reduction in survival. In this context, the negative correlation between survival and establishment represented increases in survival percentages and, although they signal favorable trends towards the development of in vitro explants, they do not guarantee the absolute establishment of explants.

\section{CONCLUSIONS}

Fall is the season of the year least recommended for explants collection of Fallgold cultivars whereas the Heritage cultivar shows higher rates of in vitro establishment in the Fall and Summer.

\section{REFERENCES}

Antoniolli LR, Silva GA, Alves SAM and MORO L (2011) Controle alternativo de podridões pós-colheita de framboesas. Pesquisa Agropecuária Brasileira 46(9): 979-985.

Buzkan N, Cetiner S and Yalcin-Mendi Y (1997) Clonal propagation of disease - free rootstocks for sour and sweet cherry by meristem culture. Acta Horticulturae 441: 329-332.

Chalfun NNJ and Pio R (2012) Aquisição e Plantio de Mudas Frutíferas. Boletim de Extensão. Editora UFLA, Lavras, MG, p. 8.

Erig AC and Fortes GRL (2002) Estabelecimento de pereira (Pyrus spp,) in vitro a partir de meristemas e gemas. Ciência Rural 32(4): 577-582.

Erig AC, Vicenzi M and Chaves AC (2003) Desinfestação de explantes de mirtilo (Vaccinium ashei Reade) visando o estabelecimento de plantas in vitro. Revista Científica Rural 8(1): 142-148.

Gonçalves ED, Pio R, Caproni CM, Zambon CR, Silva LFO and Alvarenga AA (2011) Implantação, cultivo e pós-colheita de framboesa no Sul de Minas Gerais. EPAMIG, Belo Horizonte, MG, p. 5. (Circular Técnica 145).

Han C, Zhao Y, Leonard SW and Traber MG (2007) Edible coatings to improve storability and enhance nutritional value of fresh an frozen strawberries (Fragaria X ananassa) and raspberries (Rubus idaeus). Postharvest Biology and Technology 33:67-78.

Ilha LLH (2012) Produção de amora-preta e framboesa em regiões de clima temperado. Informe Agropecuário, pequenas frutas: tecnologias de produção, 33(268): 58-68.

Karaklajić-Stajić Ž, Ružić Đ, Glišić IS and LukovićJ (2012) Vegetative pontential of plants of raspberry "Willamette" grown on different growing media and treated with different foliar fertilizers. Acta Horticulturae, Proceedings 10th International Rubus and Ribes Symposium, 946: 391-396.

Kretzschmar AA, Rufato L, Pelizza TR and Ribeiro RS (2013) A cultura da framboeseira, UDESC, Florianópolis, p.194. (Série Fruticultura, 2).

Murashige T and Skoog F (1962) A revised medium for rapid growth and biossay with tabacco tissue cultures. Physiologia Plantarum 15: 473-497.

Oliveira RP, Rocha PSG, Gularte VF and Scivittaro WB (2010) Micropropagação de framboeseira em diferentes concentrações de ferro. Revista Ciência Rural 40(12): 2598-2602.

Raseira MC, Gonçalves EDG, Trevisan R, Antunes LEC (2004) Aspectos técnicos da cultura da framboeseira. Embrapa Clima Temperado, Pelotas, p. 22. (Technical Bulletin, 120).

Rosa FC, Hansel FA, Dutra LF and Quadros KM (2006) Micropropagação de erva-mate: efeito de diferentes épocas do ano no estabelecimento in vitro de segmentos nodais. Embrapa Florestas, p. 4. (Techinical Bulletin, 163). 
Scherer-Salvaro LM, Echer MM, Guimaraes VF, Oglio EID and Fortes AMT (2009) Época de coleta dos explantes e fitorreguladores na multiplicação in vitro de citronela de Java. Scientia Agraria 10: 267-274.

Schuch MW and Peil RMN (2011) Soilless cultivation systems: A new approach in fruit plants propagation in the south of Brazil, In: International Symposium on Advanced Technologies and management towards sustainable greenhouse ecosystems-Green Syszoll. Acta Horticulturae 952: 877-883.

Tezotto-Uliana JV and Kluge RA (2013) Framboesa: cultura alternativa para pequenas propriedades rurais em regiões subtropicais. ESALQ, Piracicaba, p.33. (Technical Bulletin, 55).

Toogod A (2007) Enciclopédia de la propagación de plantas. Blume, Barcelona, 320p.

Received: June 29, 2016.

Accepted: September 14, 2016.

Published: November 25, 2016. 